\title{
Potensi Pemberian Probiotik Bifidobacterium sp., Lactococcus lactis, dan Lactobacillus sp. Terhadap Performa Produksi Ayam Petelur
}

\author{
Effect of Probiotics Bifidobacterium sp., Lactococcus lactis, and Lactobacillus sp. on \\ Growth Performance of Laying Hens
}

\author{
Putri Indra Irawan ${ }^{1 *}$, Widya Paramita Lokapirnasari ${ }^{2}$, M. Anam Al Arif ${ }^{2}$, Nenny \\ Harijani $^{3}$, Soeharsono ${ }^{4}$, Sri Hidanah ${ }^{2}$ \\ ${ }^{1}$ Magister of Veterinary Agribusiness, ${ }^{2}$ Department of Animal Husbandry, ${ }^{3}$ Department of Veterinary Public \\ Health, ${ }^{4}$ Department of Veterinary Anatomy, Faculty of Veterinary Medicine, Universitas Airlangga \\ Jl. Mulyorejo, Kampus C, Universitas Airlangga, Surabaya, Indonesia \\ *Corresponding author: putri.indrairawan@gmail.com
}

\begin{abstract}
Abstrak
Penelitian ini bertujuan untuk mengetahui pengaruh pemberian probiotik Bifidobacterium sp., Lactococcus lactis, dan Lactobacillus sp. terhadap efisiensi pakan dan massa telur ayam Isa Brown. Penelitian ini menggunakan ayam petelur strain Isa Brown sebanyak 36 ekor umur 30 minggu. Konsentrasi probiotik yang digunakan yaitu $1.2 \times 10^{9} \mathrm{CFU} / \mathrm{ml}$. Tiga perlakuan dalam penelitian yaitu P0 (tanpa diberi probiotik), P1 (diberi probiotik sebanyak $1 \mathrm{ml} / \mathrm{liter}$ air minum), dan P2 (diberi probiotik sebanyak $2 \mathrm{ml} / \mathrm{liter}$ air minum). Hasil penelitian menunjukkan bahwa nilai massa telur pada P2 berbeda nyata $(\mathrm{p}<0.05)$ dengan $\mathrm{P} 1$ dan $\mathrm{P} 0$, namun $\mathrm{P} 1$ tidak berbeda nyata $(\mathrm{p}>0.05)$ dengan P0. Berdasarkan hasil efisiensi pakan, probiotik dapat memberikan perbedaan yang nyata $(\mathrm{p}<0.05)$ antar perlakuan baik P0, P1, maupun P2. Probiotik sebanyak 2 ml/liter air minum (P2) menunjukkan nilai efisiensi pakan tertinggi (73.88 \pm 4.06$)$, sedangkan nilai efisiensi pakan terendah terjadi pada perlakuan P0. Kesimpulan penelitian ini adalah pemberian probiotik Bifidobacterium sp., L. lactis, dan Lactobacillus $s p$. dosis $1 \mathrm{ml} /$ liter air minum maupun dosis $2 \mathrm{ml} /$ liter air minum dapat meningkatkan efisiensi pakan namun tidak pada massa telur ayam Isa Brown.
\end{abstract}

Kata kunci: probiotik, performa produksi, massa telur, efisiensi pakan

\begin{abstract}
The aim of this study was to determine the effect of probiotics Bifidobacterium sp., Lactococcus lactis, and Lactobacillus sp. on feed efficiency and egg mass on Isa Brown layer. This study used 36 of 30 weeks-old laying hens Isa Brown strain. The concentration of probiotics Bifidobacterium sp., L. lactis, and Lactobacillus sp. was $1.2 \times 10^{9} \mathrm{CFU} / \mathrm{ml}$. There were three kinds of treatments, i.e. PO (none treatment), Pl (given $1 \mathrm{ml}$ of probiotics per liter of drinking water), and $P 2$ (given $2 \mathrm{ml}$ of probiotics per liter of drinking water). The results showed that the egg mass value of P2 was significantly different ( $p<0.05)$ with P1 and P0, but P1 was not significantly different $(p>0.05)$ with P0. Meanwhile for the feed efficiency, it showed that probiotics could give significant difference $(p<0.05)$ between all treatments, both PO and P1, even P2. The P2 treatment showed the highest value of feed efficiency $(73.88 \pm 4.06)$, while the lowest value of feed efficiency was the P0. It can be concluded that probiotics Bifidobacterium sp., L. lactis, and Lactobacillus sp. dose of $1 \mathrm{ml}$ per liter of drinking water and $2 \mathrm{ml}$ per liter of drinking water could increase feed efficiency but not for the egg mass on Isa Brown layer.
\end{abstract}

Keywords: probiotics, growth performance, egg mass, feed efficiency

Received: 13 Januari 2020

Revised: 30 Januari 2020

Accepted: 14 Februari 2020

\section{PENDAHULUAN}

Industri peternakan ayam di Indonesia berperan penting memenuhi kebutuhan nutrisi pangan asal hewan masyarakat. Industri peternakan ayam petelur di Indonesia kini sudah banyak dan berkembang baik dari skala kecil maupun skala besar. Dalam industri peternakan, 
biaya pakan merupakan biaya paling besar yang dibutuhkan oleh peternak. Berbagai usaha dilakukan demi menekan biaya pakan. Upaya yang dilakukan dalam menekan biaya pakan yaitu salah satunya dengan meningkatkan performa produksi ayam petelur. Pemberian suplemen tambahan menjadi salah satu alternative untuk memacu pertumbuhan atau produksi ternak unggas. Suplemen tambahan yang sering digunakan oleh peternak adalah Antibiotic Growth Promotor (AGP) dalam pakan (Kompiang, 2009).

Penggunaan AGP sebagai imbuhan pakan telah dilarang oleh pemerintah sejak 1 Januari 2018 yang diatur dalam Permentan Nomor 14 Tahun 2017 tentang Klasifikasi Obat Hewan. Peraturan tersebut ditetapkan agar kedepannya masyarakat tidak resisten terhadap antibiotik akibat mengkonsumsi produk unggas. Probiotik merupakan salah satu cara pakan tambahan yang bisa digunakan sebagai pengganti AGP untuk meningkatkan performa produksi (Suprijatna dkk., 2005).

Probiotik merupakan pakan tambahan berupa mikroorganisme hidup dalam bentuk bakteri atau jamur yang menguntungkan, yang diberikan secara oral, baik diberikan secara langsung maupun dicampur dengan pakan (Kochewad dkk., 2009). Mikroorganisme probiotik dapat meningkatkan keseimbangan mikroba di dalam saluran pencernaan. Peningkatan keseimbangan mikroba di dalam saluran pencernaan, diharapkan bisa mempengaruhi tingkat penyerapan zat nutrisi, sehingga bisa meningkatkan efisiensi pakan dan performa produksi. Berdasarkan Abdurrahman dan Yanti (2018), pemberian kombinasi probiotik dan prebiotik dapat meningkatkan penyerapan nutrisi sehingga berdampak pada peningkatan performa dan kualitas daging. Gunawan dan Sundari (2003) juga menyatakan bahwa penggunaan probiotik Lactobacillus acidophilus sebanyak $2 \%$ dan $4 \%$ dalam ransum ayam petelur dapat meningkatkan 5-11\% produksi telur dan menekan konversi pakan.

Mikroorganisme probiotik dapat menghasilkan antimikroba untuk menghambat pertumbuhan bakteri patogen di dalam saluran pencernaan. Mikroorganisme probiotik juga menghasilkan asam organik sehingga dapat menurunkankan $\mathrm{pH}$ di dalam saluran pencernaan. Penurunan $\mathrm{pH}$ menjadi asam pada saluran pencernaan akan berpengaruh pada pertumbuhan bakteri patogen di dalam saluran pencernaan. Bakteri patogen tidak akan tumbuh dengan baik pada suasana asam saluran pencernaan, sehingga bakteri baik bisa mendominasi dan berkompetisi dengan baik di dalam saluran pencernaan (Khemariya dkk., 2017; Lokapirnasari dkk., 2019).

Penelitian tentang berbagai jenis kombinasi mikroorganisme sebagai probiotik telah banyak dilakukan untuk melihat interaksi antar mikroorganisme. Penelitian Lokapirnasari dkk., (2018) menyebutkan bahwa pemberian probiotik yang dicampurkan pada air minum menunjukkan hasil yang lebih baik dibandingkan dengan yang diberikan dengan pakan. Metode penelitian ini menerapkan probiotik yang dicampur dengan air minum. Penelitian ini untuk mengetahui efek dari probiotik Bifidobacterium sp., Lactococcus lactis, dan Lactobacillus sp., dalam meningkatkan efisiensi pakan namun tidak pada massa telur ayam Isa Brown.

\section{METODE PENELITIAN}

\section{Persetujuan Etik}

Penelitian ini telah mendapatkan persetujuan laik etik dari Komite Etik Fakultas Kedokteran Hewan Universitas Brawijaya.

\section{Waktu dan Tempat}

Penelitian ini dilaksanakan di peternakan ayam petelur Baim Farm di desa Talun, Kecamatan Montong, Kabupaten Tuban pada bulan Mei-Desember 2019. Analisis pakan dilakukan di Laboratorium Pakan Ternak Fakultas Kedokteran Hewan Universitas Airlangga. Analisis telur dan pakan dilakukan di peternakan ayam tersebut setiap hari selama penelitian.

\section{Bahan Penelitian}

Materi yang digunakan dalam penelitian ini antara lain probiotik Bifidobacterium sp., $L$. 
lactis, dan Lactobacillus sp. dengan konsentrasi $1.2 \times 10^{9} \mathrm{CFU} / \mathrm{ml}$, pakan ayam komersil dari PT. New Hope dan hewan coba ayam petelur strain Isa Brown sebanyak 36 ekor umur 30 minggu. Pengambilan sampel telur dan sisa pakan dilakukan setiap hari untuk mengetahui nilai efisiensi pakan dan massa telur.

\section{Perlakuan}

Jenis penelitian adalah Rancangan Acak Lengkap. Penelitian ini menggunakan 36 ekor ayam petelur umur 30 minggu. Penelitian terdiri dari 3 perlakuan, masing-masing perlakuan terdiri dari 12 ekor ayam petelur. Perlakuan yang diberikan, antara lain: (P0) tanpa diberi probiotik, (P1) diberi probiotik sebanyak 1 $\mathrm{ml} /$ liter air minum, (P2) diberi probiotik sebanyak $2 \mathrm{ml} /$ liter air minum.

Pakan diberikan dua kali sehari yaitu pagi hari pukul 07.00 dan sore hari pukul 15.00. Probiotik diberikan dengan dicampurkan ke dalam air minum pada pagi hari pukul 07.00. Penelitian dilakukan selama 4 minggu dan 1 minggu masa adaptasi sebelum diberikan perlakuan.

\section{Variabel Pengamatan}

Variabel yang diamati pada penelitian ini yaitu performa produksi yang meliputi massa telur dan efisiensi pakan. Massa telur merupakan pembagian antara total berat telur dengan jumlah ayam. Massa telur dipengaruhi oleh berat telur dan nilai produksi harian ayam sehingga massa telur akan menunjukkan tingkat efisiensi produksi setiap hari (Kartasudjana, 2006; Pradikta dkk., 2018). Efisiensi pakan merupakan persentase dari rasio pertambahan bobot badan dengan konsumsi pakan. Nutrisi yang terkandung dari pakan juga bisa menjadi faktor yang dapat mempengaruhi tingkat efisiensi pakan (Ratriyanto dan Mentari, 2018).

\section{Analisis Data}

Data yang didapat diolah dengan menggunakan bantuan Microsoft excel, kemudian dianalisis statistik dengan menggunakan Analysis of Variance (ANOVA). Apabila diperoleh hasil yang berbeda nyata $(\mathrm{p}<0.05)$ maka dilanjutkan dengan Uji Jarak Berganda Duncan (Kusriningrum, 2012). Analisis statistik menggunakan program SPSS for Windows 21.0.

\section{HASIL DAN PEMBAHASAN}

Hasil penelitian efisiensi dan massa telur ayam petelur setelah pemberian probiotik dapat dilihat pada Tabel 1. Pemberian probiotik dapat memberikan pengaruh terhadap massa telur dan efisiensi pakan. Pada hasil massa telur, pemberian probiotik pada perlakuan $\mathrm{P} 2$ berbeda nyata $(\mathrm{p}<0.05)$ dengan perlakuan $\mathrm{P} 1$ dan perlakuan P0, namun perlakuan P1 tidak berbeda nyata ( $>0.05)$ dengan perlakuan P0. Nilai massa telur terendah $(40.86 \pm 3.38)$ terdapat pada $\mathrm{P} 2$ (Tabel 1).

Nilai massa telur dalam penelitian tergolong cukup rendah. Rendahnya nilai massa telur pada perlakuan P2 disebabkan karena dipengaruhi oleh rendahnya nilai produksi harian ayam yang sangat rendah meskipun berat telurnya cukup bagus. Hasil penelitian ini bertentangan dengan penelitian yang dilakukan oleh Pradikta dkk. (2018) bahwa nilai massa telur meningkat seiring dengan bertambahnya probiotik yang diberikan untuk ayam petelur. Faktor terpenting yang dapat mempengaruhi massa telur adalah bobot albumin dan kuning telur yang sebagian besar terdiri dari protein (Rahmaningtyas dkk., 2017). Kandungan protein dan asam amino pada telur yaitu sekitar 50\% dari bahan kering telur. Asupan protein yang tinggi akan memberikan massa telur yang tinggi pula (Istinganah dkk., 2013; Novak dkk., 2006; Joseph dkk., 2000).

Berdasarkan hasil efisiensi pakan, pemberian probiotik dapat memberikan perbedaan yang nyata $(\mathrm{p}<0.05)$ antara perlakuan baik $\mathrm{P} 0, \mathrm{P} 1$, maupun P2. P2 menunjukkan nilai efisiensi pakan tertinggi $(73.88 \pm 4.06)$, sedangkan nilai efisiensi pakan terendah terjadi pada perlakuan P0. Hasil tersebut sesuai dengan penelitian Lokapirnasari dkk. (2019) menyatakan bahwa kombinasi probiotik Bifidobacterium $s p$. dan Lactobacillus casei dapat digunakan sebagai pengganti AGP dan meningkatkan efisiensi pakan. 
Tabel 1. Nilai massa telur (g/ekor/hari) dan efisiensi pakan (\%) setelah perlakuan

\begin{tabular}{ccc}
\hline Perlakuan & $\begin{array}{c}\text { Massa Telur } \\
(\text { Mean } \pm \text { SD })\end{array}$ & $\begin{array}{c}\text { Efisiensi Pakan } \\
(\text { Mean } \pm \text { SD })\end{array}$ \\
\hline P0 & $46.45^{\mathrm{b}} \pm 4.93$ & $58.14^{\mathrm{a}} \pm 4.26$ \\
P1 & $46.60^{\mathrm{b}} \pm 2.58$ & $64.93^{\mathrm{b}} \pm 4.05$ \\
P2 & $40.86^{\mathrm{a}} \pm 3.38$ & $73.88^{\mathrm{c}} \pm 4.06$
\end{tabular}

a,b,c Superskrip berbeda pada kolom yang sama menunjukkan perbedaan signifikan $(\mathrm{p}<0.05)$

Yirga (2015) menyatakan bahwa Lactobacillus sp. selain diketahui menghasilkan asam laktat, juga menghasilkan enzim proteolitik yang dapat meningkatkan penyerapan nutrisi di dalam saluran pencernaan. Peningkatan nilai efisiensi pakan pada perlakuan yang diberikan probiotik terjadi karena adanya keseimbangan mikroba di dalam usus. Probiotik bakteri asam laktat dapat menghasilkan bakteriosin yang bisa mengurangi bakteri patogen di dalam saluran pencernaan (Lokapirnasari dkk., 2018).

Probiotik dapat menghasilkan hasil metabolisme yaitu berupa asam organik seperti asam laktat dan asam propionate. Hasil metabolisme probiotik berupa asam organik tersebut akan membuat suasana di dalam saluran pencernaan. Penurunan $\mathrm{pH}$ menjadi asam tersebut akan berpengaruh pada perumbuhan bakteri patogen di dalam saluran pencernaan. Bakteri patogen tidak akan tumbuh dengan baik pada suasana asam saluran pencernaan, sehingga bakteri baik bisa mendominasi dan berkompetisi dengan baik di dalam saluran pencernaan. Turunnya $\mathrm{pH}$ pada saluran pencernaan juga akan meningkatkan motilitas lapisan dinding usus sehingga luas permukaan dinding usus akan bertambah dan absorbsi meningkat (Khemariya dkk., 2017; Lokapirnasari dkk., 2019; Lokapirnasari, 2007).

Peningkatan nilai efisiensi pakan menunjukkan bahwa penyerapan nutrisi dilakukan secara optimal. Penyerapan nutrisi yang optimal akan berpengaruh terhadap peningkatan berat telur karena protein dalam pakan dapat diserap secara maksimal, semakin tinggi konsumsi protein maka semakin tinggi pula produksi dan bobot telur (Maknun dkk., 2015, Lokapirnasari dkk., 2019).
Penelitian ini menunjukkan peningkatan nilai efisiensi pakan dan berat telur, namun produksi harian telurnya masih rendah dan menyebabkan nilai massa telurnya juga rendah. Rendahnya produksi harian telur bisa terjadi akibat konsumsi pakan yang sedikit, karena konsumsi pakan yang rendah maka produksi telur juga akan menurun. Kurang optimalnya produksi telur juga dapat dipengaruhi faktor lain seperti lingkungan berupa suhu, kelembapan, dan pencahayaan; umur; tipe pemberian pakan dan nutrisi dalam pakan yang diberikan; dan tingkat stress (Lokapirnasari dkk., 2017).

\section{KESIMPULAN}

Dapat disimpulkan bahwa pemberian probiotik Bifidobacterium sp., L. lactis, dan Lactobacillus $s p$. dosis $1 \mathrm{ml} /$ liter air minum maupun dosis $2 \mathrm{ml} / \mathrm{liter}$ air minum dapat meningkatkan efisiensi pakan namun tidak pada massa telur ayam Isa Brown.

\section{UCAPAN TERIMA KASIH}

Peneliti mengucapkan terima kasih kepada Rektor Universitas Airlangga dan Dekan Fakultas Kedokteran Hewan, Kepala Prodi Magister Agribisnis Veteriner, Kepala Departemen Pakan Ternak Fakultas Kedokteran Hewan Universitas Airlangga dan dosen pembimbing serta dosen penguji yang telah sangat membantu proses penelitian ini.

\section{DAFTAR PUSTAKA}

Abdurrahman, Z.H., Yanti, Y. 2018. Gambaran umum pengaruh probiotik dan prebiotik 
pada kualitas daging ayam. J. Trop. Anim. Prod., 19(2), 95-104.

Gunawan, Sundari, M.M.S. 2003. Pengaruh penggunaan probiotik dalam ransum terhadap produktivitas ayam. Wartazoa, 13(3).

Istinganah, L., Mugiyono, S., Iriyanti, N. 2013. Penggunaan berbagai jenis probiotik dalam ransum terhadap produksi dan bobot telur ayam arab. Jurnal Ilmiah Peternakan, 1(1), 338-346.

Kartasudjana, R. 2006. Manajemen Ternak Unggas. Fakultas Peternakan. Universitas Padjajaran Press, Bandung.

Khemariya, P., Singh, S., Nath, G., Gulati, A.K. 2017. Probiotic Lactococcus lactis: A Review. Turk. J. Agric. Food Sci. Technol., 5(6), 556-562.

Kochewad, S.A., Chahande, J.M., Kanduri, A.B., Deshmukh, D.S., Ali, S.A., Patil. 2009. Effect of probiotic supplementation on growth performance of Osmanabadi kids. Vet. World, 2(1), 29.

Kompiang, I.P. 2009. Pemanfaatan mikroorganisme sebagai probiotik untuk meningkatkan produksi ternak unggas di Indonesia. Pengembangan Inovasi Pertanian, 2(3), 177-191.

Kusriningrum, R.S. 2012. Perancangan Percobaan. Airlangga University Press: Surabaya

Lokapirnasari, W.P. 2007. The Effect of effective microorganism to feed consumption and body weight of broiler chicken. Jurnal Protein, 14(1).

Lokapirnasari, W.P., Arif, A.A., Soeharsono, Fathimah, A., Najwan, R., Wardhani, H.C.P., Noorrahman, N.F., Huda, K., Ulfa, N., Yulianto, A.B. 2019. Improves in external and internal quality of Japanese quail (Coturnix coturnix japonica) by giving lactic acid bacteria as alternative antibiotic growth promoter. Iran. J. Microbiol., 11(5), 406-411.

Lokapirnasari, W.P., Dewi, A.R., Fathinah, A., Hidanah, S., Harijani, N., Soeharsono, Karimah, B., Andriani, A.D. 2017. Effect of probiotic supplementation on organic feed to alternative antibiotic growth promoter on production performance and economics analysis of quail. Vet. World, 10(12), 15081514.

Lokapirnasari, W.P., Sahidu, A.M., Maslachah, L., Soepranianondo, K., Yulianto, A.B., Afikasari, D., Pribadi, T.B., Hariyati, I. 2018. In vitro $\mathrm{pH}$ tolerance, bile salt resistance and antimicrobial activity of Lactobacillus plantarum isolated from crossbred cattle. Philipp. J. Vet. Med., 55, 73-78.

Lokapirnasari, W.P., Hidanah, S., Suharsono, Fathinah, A., Dewi, A.R., Adriani, A.D., Karimah, B., Nuhajati, T., Soepraniandono, K., Lamid, M. 2018. Probiotics on HDL, LDL, cholesterol and total protein of egg's quail (Coturnix coturnix japonica). J. App. Environ. Biol. Sci., 8(1).

Lokapirnasari, W.P., Pribadi, T.B., Arif, A.A., Soeharsono, Hidanah, S., Harijani, N., Najwan, R., Huda, K., Wardhani, H.C.P., Noorrahman, N.F., Yulianto, A.B. 2019. Potency of probiotics Bifidobacterium spp. And Lactobacillus casei to improve growth performance and business analysis in organic laying hens. Vet. World, 12.

Maknun, L., Sri, K., Isna, M. 2015. Performans produksi burung puyuh (Coturnix coturnix japonica) dengan perlakuan tepung limbah penetasan telur puyuh. Jurnal Ilmu-ilmu Peternakan, 25(3), 53-58. 
Novak, C., Yakout, H.M., Scheideler, S.E. 2006. The effect of dietary protein level and total sulphur amino acid: Lysine ratio on egg production parameters and egg yield in hyline W-98 hens. Poult. Sci., 85, 2195-2206.

Pradikta, R.W., Sjofjan, O., Djunaidi, I.H. 2018. Evaluasi penambahan probiotik (Lactobacillus sp.) cair dan padat dalam pakan terhadap penampilan produksi ayam petelur. Jurnal Ilmu-Ilmu Peternakan, 28(3), 203-212.

Rahmaningtyas, I.H., Yulianto, R., Prastika, D.W., Arifin, K., Oktaviana, V., Setiabudi, R.S., Purnama, M.T.E. 2017. Efektivitas tepung teritip (cirripedia $s p$ ) terhadap pertambahan berat badan dan feed convertion ratio (fcr) ayam pedaging. Surabaya. Jurnal Agro Veteriner Universitas Airlangga, 5(2).

Ratriyanto, A., Mentari, S. 2018. Pertumbuhan dan efisiensi pakan ayam broiler betina yang diberi pakan mengandung metionin cukup dan disuplementasi betaTin. Jurnal IlmuIlmu Peternakan, 28(3), 233-240.

Suprijatna, E., Umiyanti, A., Ruhyat, K. 2005. Ilmu Dasar Ternak Unggas. PT. Penebar Swadaya. Jakarta, Hal: 41.

Yirga, H. 2015. The use of probiotics in animal nutrition. J. Probiotics Health, 3(132). 